\title{
Eskişehir Ekolojik Koşullarında Azotlu Gübrelemenin Arıotu (Phacelia tanacetifolia Bentham)'nun Ot Verimi Üzerine Etkileri
}

\author{
Hande YILMAZ ${ }^{1}$ \\ *Sebahattin ALBAYRAK² \\ ${ }^{1}$ Süleyman Demirel Üniversitesi, Ziraat Fakültesi, Tarla Bitkileri Bölümü, Isparta \\ ${ }^{2}$ Ondokuzmayıs Üniversitesi, Bafra Meslek Yüksekokulu, Samsun \\ *Sorumlu yazar e-posta (Corresponding author; e-mail): sebahattinalbayrak@omu.edu.tr
}

Geliş Tarihi (Received): 12.04.2017

Kabul Tarihi (Accepted): 11.05.2017

\section{Öz}

Bu araştırma beş farklı azot dozunun (0, 3, 6, 9 ve $12 \mathrm{~kg} / \mathrm{da}$ ) iki adet arıotu (Phacelia tanacetifolia Bentham) çeşidinin (Enton ve Stala) verim ve kalite değerlerine etkisini belirlemek amacıyla 2014 ve 2015 yıllarında Eskişehir koşullarında yürütülmüştür. Araştırmada en yüksek yeşil ot ve kuru ot verimleri Enton çeşidinde dekara 6 kg olarak uygulanan azotlu gübre dozunda (sırasıyla, $2981 \mathrm{~kg}$ ve $712 \mathrm{~kg}$ ), Stala çeşidinde ise dekara $9 \mathrm{~kg}$ olarak uygulanan azotlu gübre dozunda (sırasıyla, $2103 \mathrm{~kg}$ ve $537 \mathrm{~kg}$ ) elde edilmiştir. En yüksek ham protein oranı dekara $6 \mathrm{~kg}$ ve üzeri miktarda uygulanan azotlu gübre dozlarında belirlenirken, ortalama en yüksek ham protein verimi ise 98.01 $\mathrm{kg} / \mathrm{da}$ ile dekara $9 \mathrm{~kg}$ olarak uygulanan azotlu gübre dozunda tespit edilmiştir. Araştırmada azotlu gübre dozları arttıkça arıotunun ADF ve NDF oranları azalırken, TDN değeri artış göstermiştir. En yüksek RFV değerleri kontrol parseli hariç diğer tüm azotlu gübreleme yapılan parsellerde belirlenmiştir. Araştırmadan elde edilen sonuçlara göre yeşil ot kuru ot ve ham protein verimi ile ham protein oranı, ADF ve NDF oranları ile nispi besleme değerleri dikkate alındığında Enton çeşidinin Stala çeşidine tercih edilmesi gerektiği, yüksek verim ve kalitede arıotu için ise en uygun gübre dozunun dekara 9 kg olarak uygulanan azotlu gübre olduğu sonucuna varılmıştır.

Anahtar Kelimeler: Arıotu, ot verimi, kalite, gübreleme

\section{The Effects of Nitrogen Fertilization on Forage Yield of Phacelia (Phacelia tanacetifolia Bentham) under Eskişehir Ecological Conditions}

\begin{abstract}
This research was conducted to determine the effects of four different nitrogen doses $(0,3,6,9$ and 12 $\mathrm{kg} / \mathrm{da}$ ), on yield and quality components of two phacelia (Phacelia tanacetifolia Bentham) cultivars (Enton and Stala) under Eskişehir conditions in the 2014 and 2015 growing seasons. The highest green forage and hay yields were obtained from $6 \mathrm{~kg} / \mathrm{da}$ nitrogen dose $(2981 \mathrm{~kg}$ and $712 \mathrm{~kg}$, respectively) for Enton cultivar, from 9 $\mathrm{kg} / \mathrm{da}$ nitrogen dose $(2113 \mathrm{~kg}$ and $537 \mathrm{~kg}$, respectively) for Stala cultivar. It was determined that the highest crude protein ratio at $6 \mathrm{~kg} / \mathrm{da}$ or more nitrogen fertilizations, the highest crude protein yield was $98.01 \mathrm{~kg} / \mathrm{da}$ at the $9 \mathrm{~kg} / \mathrm{da}$ nitrogen fertilization. While increasing nitrogen doses, ADF and NDF contents were decreased, TDN content of phacelia cultivars were increased. The highest RFV value was determined at the all nitrogen fertilization doses except control plot. In conclusion, it was regarded that green forage yield, hay yield, crude protein ratio, crude protein yield and relative feed value, Enton cultivar can be preferred over Stala cultivar. It is possible to obtain high forage yield and good quality with $9 \mathrm{~kg} / \mathrm{da}$ nitrogen application in similar ecologies.
\end{abstract}

Keywords: Phacelia, forage yield, quality, fertilization

\section{Giriş}

$\mathrm{K}$

uzey Amerika orijinli, tek yıllık, uzun gün bitkisi olan arıotu (Phacelia tanacetifolia Benth.) dünyanın birçok bölgesinde bulunmakla birlikte özellikle Avrupa'da yaygın olarak kullanılmaktadır. Çiçeklerinin bol miktarda polen ve nektar oluşturması yanında, uzun süreli çiçekte kalması (6-8 hafta) nedeniyle Kuzey Amerika ve Avrupa ülkelerinde bu bitkiden "Arı Merası" olarak yararlanılmaktadır. Arı merası amacıyla kullanılan arıotunun çiçekleri büyük ölçüde azaldığı zaman biçilerek kaba yem kaynağı 
(silaj, yeşil gübre, vb.) olarak değerlendirilebilir. $\mathrm{Bu}$ durum arıotunun ekonomik kullanım olanaklarını artırmaktadır (Akkurt, 2013).

Bitkilerde verim ve kaliteyi arttırmada yararlanılan en etkili yetiştirme tekniği uygulamalarından biri de gübrelemedir. Yapılan çalışmalarda yetiştirme teknikleri içerisinde verimi arttırmada en büyük payın gübreye ait olduğu ve gübreleme ile \%60'a varan ürün artışı sağlanabileceği belirtilmektedir (Sezer 1991). Fakat azotlu gübre uygulamaları ile bazı yıllarda verim artışı sağlanabilirken, bazen gübreleme hatalarından dolayı gübrelemenin verime olumlu etkileri görülemeyebilir (Ercan ve Bildik 1993). Gromadzinski (1976) Polanya'da arıotunda yaptıkları çalışmada dekara 6 kg'a kadar uygulanan azotlu gübrelemenin arıotunun verim ve kalitesini artırdığını ancak dekara 12 kg'a çıkan azotlu gübrelemede verim artışının düştüğünün bildirmişlerdir. Kucharski (1992), Arıotuna uygulana amonyum nitrat ve üre formundaki azotlu gübrelemenin organik gübrelere göre otun verim ve kalitesini daha yüksek oranda artırdığını ifade etektedir. Djordjevic ve ark (2005) arıotunda yaptıkları çalışmada ise dekara $4.5 \mathrm{~kg}$ olarak uygulanan azotlu gübrelemenin arıotunun kalitesine etki etmediğini tespit etmişlerdir. Wilczewski ve ark. (2006), arıotunda dekara uygulanan $9 \mathrm{~kg}$ azotlu gübrelemenin kontrol parsellerine göre yeşil ot verimini \%82.5 artırdığını belirtmişlerdir. Wilczewski ve ark. (2008), Polanya'da arıotu ile yapmış oldukları çalışmada dekara 9 kg'a kadar uygulanan azotlu gübrelemenin arıotunun verimini artırdığını ancak ham protein oranında önemli bir değişiklik olmadığını bildirmişlerdir. Wilczewski ve ark. (2009), arıotunda dekara 4.5 kg dan 9 kg'a kadar verilen azot dozunun üretilen otun verim ve kalitesini artırdığı belirtmişleridir.

$\mathrm{Bu}$ araştırmada, Eskişehir ve benzeri ekolojilere sahip olan bölgeler için bazı arıotu çeşitlerinin en uygun azotlu gübre dozları belirlenerek yöre çiftçisinin daha yüksek verim ve kalitede hayvansal kaba yem üretme imkanlarının sağlanması amaçlanmıştır.

\section{Materyal ve Yöntem}

Bu araştırma, 2014 ve 2015 yılı Mart-Temmuz ayları arasında Eskişehir, Tepebaşına bağlı Turgutlar köyünde çiftçi arazisinde yürütülmüştür. Deneme yeri $37^{\circ}$ $47^{\prime}$ Kuzey enlem ve $30^{\circ} 31^{\prime}$ Doğu boylamında olup, denizden yüksekliği 782 m'dir. Deneme alanı toprağı tınlı, hafif alkali, elverişli fosfor ve potasyum yönünden zengin, organik madde bakımından ise fakirdir. Denemenin yürütüldüğü Mart-Temmuz ayları arasında 2014 ve 2015 yıllarında; toplam yağış miktarı 254.1 ve $223.6 \mathrm{~mm}$, sıcaklık ortalaması 14.16 ${ }^{\circ} \mathrm{C}$ ve $14.21{ }^{\circ} \mathrm{C}$, nispi nem oranı ise $\% 58.6$ ve \%58.9 olurken uzun yıllar ortalama değerleri ise sırasıyla, $166.6 \mathrm{~mm}, 14.28^{\circ} \mathrm{C}$ ve $\% 59.2 \mathrm{dir}$.

Araştırma materyallerini oluşturan arıotu (Phacelia tanacetifolia Bentham)'nun Stala ve Enton çeşitleri Ankara Üniversitesi, Ziraat Fakültesi, Tarla Bitkileri Bölümü'nden temin edilmiştir. Azotlu gübre dozları dekara 0 , $3,6,9$ ve $12 \mathrm{~kg}$ olarak yarısı ekimle birlikte geriye kalanı bitkileri 4-5 yapraklı olduğu dönemde uygulanmış olup, çalışmada \%33'lük amonyum nitrat gübresi kullanılmıştır. Ayrıca ekimle birlikte tüm parsellere dekara $5 \mathrm{~kg}$ fosforlu gübre (Triple süper fosfat, \%46) uygulanmıştır.

Deneme, "Tesadüf bloklarında faktöryel düzen” e göre 3 tekrarlamalı olarak her iki yılda da mart ayının 3. haftasında kurulmuştur. Denemede sıra arası $30 \mathrm{~cm}$, parsel boyu 5 m olup her bir parsel 6 sıradan oluşmuştur. Hasat, arıotu bitkilerinin tam çiçeklenme döneminde, kenarlardan birer sıra ve parsel baş ve sonundan ise 0.5 m'lik alan çıkarıldıktan sonra elle yapılmıştır.

Araştırmada, yeşil ot verimi ( $\mathrm{kg} / \mathrm{da})$, kuru ot verimi $(\mathrm{kg} / \mathrm{da})$, ham protein oranı (\%), ham protein verimi $(\mathrm{kg} / \mathrm{da})$, asit çözücülerde çözünmeyen lif (ADF), nötr çözücülerde çözünmeyen lif (NDF), toplam sindirilebilir besin maddesi (TDN) ve nispi besleme değeri (RFV) belirlenmiştir (Albayrak ve ark. 2009). Ham protein analizi Kjeldahl, ADF ve NDF analizleri ise ANKOM-220 cihazı ile yapılmıştır.

$$
\begin{aligned}
& \mathrm{TDN}=(-1.291 \times \mathrm{ADF})+101.35 \\
& \mathrm{RFV}=(120 / \% \mathrm{NDF}) \times 88.9-(0.779 \times \mathrm{ADF}) \times 0.775
\end{aligned}
$$

Denemeye ait veriler SAS (1998) bilgisayar programından yararlanılarak değerlendirilmiştir. Araştırma sonuçlarında iki yıllık verilerin ortalama değerleri kullanılmıştır. İstatistiki analiz sonucunda önemli farklılık ortaya çıktığında, ortalamaların karşılaştırılması için \%5 önemlilik düzeyinde Asgari Önemli Fark (LSD) testi uygulanmıştır. 


\section{Bulgular ve Tartışma}

\section{Yeşil ot verimi (kg/da)}

Arıotu çeşitleri, gübre dozları ve çeşit $x$ gübre dozları interaksiyonu arasındaki fark \%1 düzeyinde istatistiki yönden önemli bulunmuştur(Çizelge 1). Enton çeşidinin yeşil ot verimi $(2536 \mathrm{~kg} / \mathrm{da})$ Stala çeşidinden yüksek bulunmuştur (1755 kg/da). Dekara 6 ve $9 \mathrm{~kg}$ uygulanan azotlu gübre dozlarından en yüksek yeşil ot verimi elde edilirken (sırasıyla, 2496 ve $2409 \mathrm{~kg} / \mathrm{da}$ ) hiç gübre uygulanmayan parsellerin ortalama verimi $1524 \mathrm{~kg} / \mathrm{da}$ olmuştur (Çizelge 2). Enton çeşidinde en yüksek yeşil ot verimleri dekara 6 ve $9 \mathrm{~kg}$ gübre dozlarında belirlenirken (sırasıyla, 2981 ve $2888 \mathrm{~kg} / \mathrm{da}$ ), Stala çeşidinde en yüksek yeşil ot verimleri dekara $9 \mathrm{~kg}$ uygulanan gübre dozunda $(2103 \mathrm{~kg} / \mathrm{da})$ belirlenmiştir. Çeşitlerin azotlu gübre dozlarına karşı vermiş olduğu tepkilerin farklılığından dolayı çeşit x gübre dozu interaksiyonları da önemli bulunmuştur.

Gromadzinski (1976) Polanya'da arıotunda yaptıkları çalışmada dekara 6 kg'a kadar uygulanan azotlu gübrelemenin arıotunun verim ve kalitesini artırdığını ancak dekara 12 kg'a çıkan azotlu gübrelemede verim artışının düştüğü bulgusu araştırma bulgularımızla uyum içersindedir. Benzer şekilde Wilczewski ve ark. (2008), Polanya'da arıotu ile yapmış oldukları çalışmada dekara 9 kg'a kadar uygulanan azotlu gübrelemenin arıotunun verimini artırdığını bildiren sonuç ta araştırmamızla uygunluk göstermektedir. Dağ (2013) Van koşullarında dekara $0,3,6,9$ ve $12 \mathrm{~kg}$ olarak uygulanan azotlu gübrelemenin arıotunun verim ve kalitesi üzerine etkilerinin incelendiği araştırmada; kontrol parsellerinde $583.8 \mathrm{~kg} / \mathrm{da}$ olan yeşil ot veriminin dekara 9 ve $12 \mathrm{~kg}$ olarak uygulanan azotlu gübre dozlarında sırasıyla, 1203.2 ve $1366.4 \mathrm{~kg} /$ da'a yükseldiğini, Ateş ve ark. (2014) Tekirdağ koşullarında dekara 0, 3, 6, 9, 12 ve 15 kg olarak uygulanan azotlu gübrelemenin arıotunun verim ve kalitesine etkilerinin incelendiği araştırmada; kontrol parsellerinde dekara $2540 \mathrm{~kg}$ olan yeşil ot veriminin $15 \mathrm{~kg} / \mathrm{da}$ azot dozunda $4673 \mathrm{~kg} /$ da yükseldiğini araştırma sonucunda yüksek verim ve kalitede arıotu için dekara $9 \mathrm{~kg}$ olarak uygulanan azotlu gübrelemenin en uygun gübre dozu olduğunu tespit etmişlerdir. Dağ (2013) ve Ateş ve ark. (2014) araştırma bulguları çalışma sonuçlarımız ile uyum içerisindedir.

Çizelge 1. Arıotu çeşitleri ve farklı azotlu gübre dozları kullanılarak belirlenen yeşil ot verimi, kuru ot verimi, ham protein oranı ve ham protein verimine ait varyans analiz sonuçları (Kareler ortalaması)

Table 1. Variance analysis of forage yield, hay yield, crude protein ratio and crude protein yield at pacelia cultivars and different nitrogen doses (mean squares)

\begin{tabular}{lccccc}
\hline Varyasyon Kaynakları & S.D & Yeşil ot verimi & Kuru ot verimi & Ham protein oranı & Ham protein verimi \\
\hline Yıl & 1 & 2653 & $7820^{*}$ & $5.55^{* *}$ & $582^{* *}$ \\
Blok(yıl) & 4 & $120838^{* *}$ & 4340 & 0.04 & 92 \\
Çeşit & 1 & $9863382^{* *}$ & $545878^{* *}$ & $6.82^{* *}$ & $13896^{* *}$ \\
Yıl x çeşit & 1 & 904 & 93 & 0.16 & 31 \\
Gübre & 4 & $1839664^{* *}$ & $161195^{* *}$ & $25.40^{* *}$ & $6076^{* *}$ \\
YIl x gübre & 4 & 1432 & 409 & 0.10 & 3 \\
Çeşit x gübre & 4 & $119358^{* *}$ & $5264^{*}$ & 0.77 & $185^{* *}$ \\
Yılxçeşitxgübre & 4 & 2536 & 519 & 0.04 & 12 \\
Hata & 36 & 25296 & 62685 & 0.50 & 38.75 \\
\hline VK $(\%)$ & 7.47 & 8.19 & 4.93 & 8.34 & \\
\hline
\end{tabular}

* $0.05,{ }^{* *} 0.01$ önem düzeyinde farklılığı göstermektedir

(*) $\left.0.05,{ }^{* *}\right) 0.01$ significant probability level

Çizelge 2. Çeşit x gübre dozu interaksiyonu yeşil ot verimi ortalamaları $(\mathrm{kg} / \mathrm{da})$

Table 2. Cultivar $x$ nitrogen doses interactions of forage yield means ( $\mathrm{kg} / \mathrm{da}$ )

\begin{tabular}{|c|c|c|c|}
\hline \multirow{2}{*}{ Azotlu gübre tozları (kg/da) } & \multicolumn{2}{|c|}{ Çeşitler } & \multirow{2}{*}{ Ortalame } \\
\hline & Enton & Stala & \\
\hline 0 & $1897 \mathrm{de}$ & $1151 \mathrm{~g}$ & $1524 \mathrm{D}$ \\
\hline 3 & $2368 \mathrm{bc}$ & $1595 \mathrm{f}$ & 1982 C \\
\hline 6 & 2981 a & 1837 ef & $2409 \mathrm{~A}$ \\
\hline 9 & 2888 a & $2103 \mathrm{~cd}$ & 2496 A \\
\hline 12 & $2545 \mathrm{~b}$ & $1938 \mathrm{de}$ & 2242 B \\
\hline Ortalama & $2536 \mathrm{~A}$ & $1755 \mathrm{~B}$ & 2131 \\
\hline
\end{tabular}




\section{Kuru ot verimi (kg/da)}

Arıotu çeşitleri ve gübre dozları arasındaki farklıklar \%1 düzeyinde, yıl ve çeşit x gübre dozları interaksiyonu arasındaki fark ise $\% 5$ düzeyinde istatistiki yönden önemli bulunmuştur (Çizelge 1). Yeşil ot veriminde olduğu gibi kuru ot veriminde de Enton çeşidi Stala çeşidinden daha yüksek verim vermiştir. Azotlu gübre dozları arttıkça arıotu çeşitlerinde kuru ot verimi artarken en yüksek kuru ot verimi dekara $629 \mathrm{~kg}$ ile $9 \mathrm{~kg}$ 'lık gübre dozunda belirlenmiştir. Dekara $12 \mathrm{~kg}$ uygulanan gübre dozunda ise kuru ot verimleri azalmıştır. Yeşil ot veriminde olduğu gibi kuru ot veriminde de Enton çeşidinde en yüksek kuru ot verimleri dekara 6 ve $9 \mathrm{~kg}$ gübre dozlarında belirlenirken (sırasıyla, 712 ve $722 \mathrm{~kg} / \mathrm{da}$ ), Stala çeşidinde en yüksek kuru ot verimleri dekara $9 \mathrm{~kg}$ uygulanan gübre dozunda $(537 \mathrm{~kg} / \mathrm{da})$ belirlenmiştir. Farklı gübre dozlarının arıtu çeşitlerinin kuru ot verim değerlerinde farklı sonuçlar ortaya çıkarması çeşit $x$ gübre dozu interaksiyonunun önemli çıkmasının nedeni olarak açıklanabilir (Çizelge $3)$. Arıotunda azotlu gübre dozlarına bağlı olarak üretilen otun kuru ot veriminde de artışa neden olduğu pek çok araştırıcı tarafından da vurgulanmıştır (Wilczewski ve ark. 2008; Wilczewski ve ark. 2009; Dağ, 2013; Ateş ve ark. 2014). Belirtilen araştırıcıların arıotu için bulmuş olduğu sonuçlar araştırma bulgularımızla benzerlik göstermektedir.

\section{Ham protein oranı (\%)}

Arıotu çeşitleri ve gübre dozları arasındaki farklıklar ile yıllar \%1 düzeyinde istatistiki yönden önemli bulunurken, çeşit $x$ gübre dozları interaksiyonu ise istatistiki yönden önemsiz bulunmuştur (Çizelge 1). Enton çeşidinin ham protein oranı (\%14.68) Stala çeşidinden (\%14.00) yüksek bulunmuştur. Her iki çeşidin ortalaması olarak gübre dozları arttıkça ham protein oranlarında da artış tespit edilmiştir. Konrol parsellerinin ortalama ham protein oranı \%12.23 iken dekara $12 \mathrm{~kg}$ azot dozu uygulanan parsellerde bu oran $\% 15.61$ 'e yükselmiştir (Çizelge 4).
Enton çeşidinde en yüksek ham protein oranı \%15.82 ile dekara $9 \mathrm{~kg}$ uygulanan azotlu gübre dozundan elde edilirken, Stala çeşidinde en yüksek ham protein oranı \%15.63 ile dekara $12 \mathrm{~kg}$ uygulanan azotlu gübre dozundan elde edilmiştir (Çizelge 4). Geren ve Kaymakkavak (2007) arıotunun ham protein oranını \%12.114.1 olarak belirlediği araştırma sonucu bulgularımızla benzerlik gösterirken, Ateş (2012) ise arıotunun ham protein oranını \%10.33 olarak bulduğu sonuç araştırma bulgularımızdan düşük bulunmuştur. Azotlu gübre dozlarına bağlı olarak azot dozu arttıkça arıotunun ham protein oranının da artığını bildiren Dağ, 2013 ve Ateş ve ark. 2014'un bulguları araştırma sonuçlarımızla tam bir uyum içersindedir.

\section{Ham protein verimi (kg/da)}

Arıotu çeşitleri, gübre dozları, yıllar ve çeşit $x$ gübre dozları interaksiyonu arasındaki fark $\% 1$ düzeyinde istatistiki yönden önemli bulunmuştur (Çizelge 1). Enton çeşidinin ortalama ham protein verimi $(89.85 \mathrm{~kg} / \mathrm{da})$ Stala çeşidinin ortalama ham protein verimi $(59.42 \mathrm{~kg} / \mathrm{da}$ )'nden yüksek olmuştur. Azotlu gübre dozlarının ortalaması olarak en yüksek ham protein verimi ise dekara $9 \mathrm{~kg}$ olarak uygulanan dozdan $(98.01 \mathrm{~kg} / \mathrm{da})$ elde edilmiştir. Arıotu çeşitlerinde azotlu gübrelemeye bağlı olarak ham protein verimindeki artış oranlarının farklıı̆ı çeşit $x$ gübre interaksiyonun önemli çıkmasından kaynaklanmaktadır. En yüksek ham protein verimleri dekara 108.39 ve 114.24 $\mathrm{kg}$ ile Enton çeşidinde ve dekara 6 ve $9 \mathrm{~kg}$ olarak uygulanan azotlu gübre dozlarında belirlenmiştir. Stala çeşidinde ise en yüksek ham protein verimi $81.78 \mathrm{~kg} / \mathrm{da}$ ile dekara $9 \mathrm{~kg}$ olarak uygulanan azotlu gübre dozunda tespit edilmiştir (Çizelge 5). Ham protein veriminin belirlenmesinde bitkilerin ham protein oranları ve kuru ot verimi değerleri birlikte değerlendirildiğinden ortaya çıkan farklılıklar özellikle bu iki verim öğesinin birlikte değerlendirilmesi gerektiğini göstermektedir. Nitekim kuru ot veriminin yüksek olduğu dekara $9 \mathrm{~kg}$ olarak uygulanan azotlu gübre dozundaki ham protein veriminin de en yüksek olduğu gübre dozu olmuştur.

Çizelge 3. Çeşit x gübre dozu interaksiyonu kuru ot verimi ortalamaları $(\mathrm{kg} / \mathrm{da})$

Table 3. Cultivar $x$ nitrogen doses interactions of hay yield means $(\mathrm{kg} / \mathrm{da})$

\begin{tabular}{|c|c|c|c|}
\hline \multirow{2}{*}{ Azotlu gübre dozları (kg/da) } & \multicolumn{2}{|c|}{ Çeşitler } & \multirow{2}{*}{ Ortalama } \\
\hline & Enton & Stala & \\
\hline 0 & 419 de & $244 \mathrm{f}$ & $332 \mathrm{E}$ \\
\hline 3 & $558 \mathrm{c}$ & 376 e & $467 \mathrm{D}$ \\
\hline 6 & $712 \mathrm{a}$ & $450 \mathrm{~d}$ & $581 \mathrm{~B}$ \\
\hline 9 & $722 \mathrm{a}$ & $537 \mathrm{c}$ & $629 \mathrm{~A}$ \\
\hline 12 & $612 b$ & $463 d$ & $538 \mathrm{C}$ \\
\hline Ortalama & $605 \mathrm{~A}$ & $414 \mathrm{~B}$ & 509 \\
\hline
\end{tabular}


Çizelge 4.Çeşit x gübre dozu interaksiyonu ham protein oranı ortalamaları (\%) Table 4. Cultivar $x$ nitrogen doses interactions of crude protein ratio means $(\mathrm{kg} / \mathrm{da})$

\begin{tabular}{|c|c|c|c|}
\hline \multirow{2}{*}{ Azotlu gübre dozları (kg/da) } & \multicolumn{2}{|c|}{ Çeşitler } & \multirow{2}{*}{ Ortalama } \\
\hline & Enton & Stala & \\
\hline 0 & 12.93 & 11.54 & $12.23 \mathrm{D}$ \\
\hline 3 & 13.80 & 13.16 & $13.48 \mathrm{C}$ \\
\hline 6 & 15.27 & 14.50 & $14.89 \mathrm{~B}$ \\
\hline 9 & 15.82 & 15.22 & $15.52 \mathrm{~A}$ \\
\hline 12 & 15.59 & 15.63 & $15.61 \mathrm{~A}$ \\
\hline Ortalama & $14.68 \mathrm{~A}$ & $14.00 \mathrm{~B}$ & 14.04 \\
\hline
\end{tabular}

Çizelge 5. Çeşit x gübre dozu interaksiyonu ham protein verimi ortalamaları $(\mathrm{kg} / \mathrm{da})$ Table 5. Cultivar $x$ nitrogen doses interactions of crude protein yield means ( $\mathrm{kg} / \mathrm{da})$

\begin{tabular}{|c|c|c|c|}
\hline \multirow{2}{*}{ Azotlu gübre dozları (kg/da) } & \multicolumn{2}{|c|}{ Çeşitler } & \multirow{2}{*}{ Ortalama } \\
\hline & Enton & Stala & \\
\hline 0 & $54.31 \mathrm{f}$ & $28.15 \mathrm{~g}$ & $41.23 \mathrm{D}$ \\
\hline 3 & $77.03 \mathrm{~cd}$ & $49.48 \mathrm{f}$ & $63.26 \mathrm{C}$ \\
\hline 6 & 108.39 a & $65.29 \mathrm{e}$ & 86.84 B \\
\hline 9 & $114.24 \mathrm{a}$ & $81.78 \mathrm{c}$ & $98.01 \mathrm{~A}$ \\
\hline 12 & $95.31 \mathrm{~b}$ & $72.39 \mathrm{de}$ & $83.85 \mathrm{~B}$ \\
\hline Ortalama & $89.85 \mathrm{~A}$ & $59.42 \mathrm{~B}$ & 74.64 \\
\hline
\end{tabular}

\section{Asit Çözücülerde Çözünmeyen Lif (ADF)}

Arıotunda ADF oranı bakımından çeşitler arasındaki farkılık \%5, gübre dozları arasındaki farklıklar ise $\% 1$ düzeyinde istatistiki yönden önemli bulunurken, yıllar ve çeşit $\mathrm{x}$ gübre dozları interaksiyonu ise istatistiki yönden önemsiz bulunmuştur (Çizelge 6).

Enton çeşidinin ADF oranı (\%34.52) Stala çeşidinden (\%35.14) düşük bulunmuştur. Her iki çeşidin ortalamasına bakıldığında ise gübre dozları $9 \mathrm{~kg} / \mathrm{da}$ 'a kadar arttıkça $A D F$ oranlarında azalış tespit edilmiştir. Kontrol parsellerinin ortalama ADF oranı \%36.26 iken dekara $12 \mathrm{~kg}$ azot dozu uygulanan parsellerde bu oran \%33.73'e düşmüştür. Hem
Enton hem de Stala çeşitlerinde en düşük ADF oranları dekara $12 \mathrm{~kg}$ olarak uygulanan azotlu gübre dozlarında (sırasıyla, \%33.65 ve 33.82) belirlenmiştir (Çizelge, 7). Ateş (2012) arıtunda ADF oranını \%38.1 olarak bulduğu sonuç araştırma bulgularımızdan kısmen yüksek bulunmuştur. Ateş ve ark. (2014) Tekirdağ koşullarında dekara $0,3,6,9,12$ ve $15 \mathrm{~kg}$ olarak uygulanan azotlu gübrelemenin arıotunun verim ve kalitesine etkilerinin incelendiği araştırmada; kontrol parsellerinde \%37.7 olan ADF oranının dekara $15 \mathrm{~kg}$ olarak uygulanan gübre dozundan \%39.2'ye çıktığını ancak gübre dozlarının arıotunun ADF oranına etkisinin istatistiki olarak önemsiz olduğunu bildirmişlerdir.

Çizelge 6. Arıotu çeşitleri ve farklı azotlu gübre dozları kullanılarak belirlenen ADF, NDF, TDN ve RFV oranlarına ait varyans analiz sonuçları (Kareler ortalaması)

Table 6. Variance analysis of forage yield, hay yield, crude protein ratio and crude protein yield at pacelia cultivars and different nitrogen doses (mean squares)

\begin{tabular}{cccccl}
\hline Varyasyon Kaynakları & S.D & ADF & NDF & TDN & RFV \\
\hline Yıl & 1 & 1.54 & 2.37 & 2.57 & 2.40 \\
Blok(yıl) & 4 & $2.93^{*}$ & $2.77^{* *}$ & $4.89^{*}$ & $23.98^{*}$ \\
Çeşit & 1 & $2.72^{*}$ & 0.62 & $9.56^{*}$ & 15.0 \\
Yıl x çeşit & 1 & 0.36 & 0.49 & 0.59 & 1.07 \\
Gübre & 4 & $10.59^{* *}$ & $22.91^{* *}$ & $17.65^{* *}$ & $311^{* *}$ \\
Yıl x gübre & 4 & 0.19 & 0.48 & 0.31 & 0.32 \\
Çeşit x gübre & 4 & 0.38 & 1.53 & 0.64 & 8.58 \\
Yılxçeşitxgübre & 4 & 0.44 & 0.59 & 0.73 & 1.23 \\
Hata & 36 & 0.80 & 0.66 & 1.33 & 8.11 \\
\hline VK (\%) & & 2.56 & 1.79 & 2.04 & 2.23 \\
\hline
\end{tabular}

* $0.05,{ }^{* *} 0.01$ önem düzeyinde farklılığı göstermektedir

$\left({ }^{*}\right) 0.05,\left({ }^{* *}\right) 0.01$ significant probability level 
Çizelge 7. Çeşit x gübre dozu interaksiyonu ADF oranı ortalamaları (\%)

Table 7. Cultivar $x$ nitrogen doses interactions of ADF content means (\%)

\begin{tabular}{|c|c|c|c|}
\hline \multirow{2}{*}{ Azotlu gübre dozları (kg/da) } & \multicolumn{2}{|c|}{ Çeşitler } & \multirow{2}{*}{ Ortalama } \\
\hline & Enton & Stala & \\
\hline 0 & 36.05 & 36.46 & $36.26 \mathrm{~A}$ \\
\hline 3 & 34.78 & 35.40 & 35.09 B \\
\hline 6 & 34.12 & 35.24 & 34.68 B \\
\hline 9 & 33.99 & 34.76 & $34.37 \mathrm{BC}$ \\
\hline 12 & 33.65 & 33.82 & $33.73 \mathrm{C}$ \\
\hline Ortalama & $34.52 \mathrm{~B}$ & $35.14 \mathrm{~A}$ & 34.83 \\
\hline
\end{tabular}

Çizelge 8. Çeşit x gübre dozu interaksiyonu NDF oranı ortalamaları (\%)

Table 8. Cultivar $x$ nitrogen doses interactions of NDF content means (\%)

\begin{tabular}{|c|c|c|c|}
\hline \multirow{2}{*}{ Azotlu gübre dozları $(\mathrm{kg} / \mathrm{da})$} & \multicolumn{2}{|c|}{ Çeşitler } & \multirow{2}{*}{ Ortalama } \\
\hline & Enton & Stala & \\
\hline 0 & 46.82 & 48.01 & $47.41 \mathrm{~A}$ \\
\hline 3 & 45.69 & 46.04 & $45.86 \mathrm{~B}$ \\
\hline 6 & 44.63 & 44.82 & $44.72 \mathrm{C}$ \\
\hline 9 & 44.31 & 44.42 & $44.36 \mathrm{CD}$ \\
\hline 12 & 44.42 & 43.61 & $44.01 \mathrm{D}$ \\
\hline Ortalama & 45.17 & 45.38 & 45.28 \\
\hline
\end{tabular}

\section{Nötr Çözücülerde Çözünmeyen Lif (NDF)}

Arıotuna uygulanan azotlu gübre dozları arasındaki farklıklar \%1 düzeyinde istatistiki yönden önemli bulunmuştur (Çizelge 6). Enton ve Stala çeşitlerinin NDF oranları arasında istatistiki olarak farklılık olmamıştır (sırasıyla, $\% 45.17$ ve 45.38). Buna karşılık gübre dozları arttıkça NDF oranlarında azalış tespit edilmiştir. Kontrol parsellerinin ortalama NDF oranı $\% 47.41$ iken dekara $12 \mathrm{~kg}$ azot dozu uygulanan parsellerde bu oran \%44.01'e düşmüştür. En düşük NDF oranı \%44.31 ile Enton çeşidinde dekara $9 \mathrm{~kg}$ olarak uygulanan azotlu gübre dozlarında belirlenirken, Stala çeşidinde ise en düşük NDF oranı \%43.61 ile dekara $12 \mathrm{~kg}$ olarak uygulanan azotlu gübre dozunda tespit edilmiştir (Çizelge 8). Ateş (2012) arıotunda NDF oranını \%44.7 olarak bulduğu sonuç araştırma bulgularımızla benzerlik göstermektedir. Ateş ve ark. (2014) Tekirdağ koşullarında dekara 0 , $3,6,9,12$ ve $15 \mathrm{~kg}$ olarak uygulanan azotlu gübrelemenin arıotunun verim ve kalitesine etkilerinin incelendiği araştırmada; kontrol parsellerinde \%45.5 olan NDF oranının dekara $15 \mathrm{~kg}$ olarak uygulanan gübre dozunda $\% 46.8$ 'e çıktığını ancak gübre dozlarının arıotunun NDF oranına etkisinin istatistiki olarak önemsiz olduğunu bildirmişlerdir. Bununla birlikte araştırıcılar yüksek verim ve kalitede arıotu için dekara 9 veya $12 \mathrm{~kg}$ olarak uygulanan azotlu gübrelemenin en uygun gübre dozu olduğunu bildiren görüşleri araştırma sonuçlarımızla benzerlik göstermektedir.

\section{Toplam Sindirilebilir Besin Maddesi (TDN)}

Arıotu çeşitler arasındaki farklılık \%5, gübre dozları arasındaki farklıklar ise \%1 düzeyinde istatistiki yönden önemli bulunurken, yıllar ve çeşit x gübre dozları interaksiyonu ise istatistiki yönden önemsiz bulunmuştur (Çizelge 6).

Enton çeşidinin TDN oranı (\%56.79) Stala çeşidinden (\%55.99) yüksek bulunmuştur. Her iki çeşidin ortalaması olarak gübre dozları arttıkça TDN oranlarında artış belirlenmiştir. Kontrol parsellerinin ortalama TDN oranı \% 54.55 iken dekara $12 \mathrm{~kg}$ azot dozu uygulanan parsellerde bu oran $\% 57.80$ 'e yükselmiştir. Hem Enton hem de Stala çeşitlerinde en yüksek TDN oranları dekara $12 \mathrm{~kg}$ olarak uygulanan azotlu gübre dozlarında (sırasıyla, \%57.91 ve 57.69) belirlenmiştir (Çizelge, 9). TDN, yemin yapısında bulunan sindirilebilir besin maddelerinin toplamını ifade eder. TDN oranı yemin ADF içeriğiyle yakından ilişkilidir. Otun ADF oranı arttıkça TDN oranında bir azalma olur ki bu durum yemin sindirilebilirliğini önemli ölçüde azaltır (Aydın ve ark. 2010). Nitekim arıotu çeşitlerinde azotlu gübre dozları arttıkça TDN oranlarında da artış tespit edilmiştir.

\section{Nispi Besleme Değeri (RFV)}

Azotlu gübre dozları arasındaki farklıklar \%1 düzeyinde istatistiki yönden önemli bulunurken, yıllar, arıotu çeşitleri ve çeşit $x$ gübre dozları interaksiyonu ise istatistikiyönden 
Çizelge 9. Çeşit x gübre dozu interaksiyonu TDN oranı ortalamaları (\%)

Table 9. Cultivar $x$ nitrogen doses interactions of TDN content means (\%)

\begin{tabular}{|c|c|c|c|}
\hline \multirow{2}{*}{ Azotlu gübre dozları (kg/da) } & \multicolumn{2}{|c|}{ Çeşitler } & \multirow{2}{*}{ Ortalama } \\
\hline & Enton & Stala & \\
\hline 0 & 54.81 & 54.28 & $54.55 \mathrm{C}$ \\
\hline 3 & 56.46 & 55.65 & $56.05 \mathrm{~B}$ \\
\hline 6 & 57.29 & 55.86 & $56.57 \mathrm{~B}$ \\
\hline 9 & 57.47 & 56.48 & $56.98 \mathrm{AB}$ \\
\hline 12 & 57.91 & 57.69 & $57.80 \mathrm{~A}$ \\
\hline Ortalama & $56.79 \mathrm{~A}$ & $55.99 \mathrm{~B}$ & 56.39 \\
\hline
\end{tabular}

Çizelge 10. Çeşit x gübre dozu interaksiyonu RFV oranı ortalamaları (\%)

Table 10. Cultivar $x$ nitrogen doses interactions of RFV content means (\%)

\begin{tabular}{|c|c|c|c|}
\hline \multirow{2}{*}{ Azotlu gübre dozları (kg/da) } & \multicolumn{2}{|c|}{ Çeşitler } & \multirow{2}{*}{ Ortalama } \\
\hline & Enton & Stala & \\
\hline 0 & 122 & 118 & $120 D$ \\
\hline 3 & 127 & 125 & $126 \mathrm{C}$ \\
\hline 6 & 128 & 128 & $128 \mathrm{~B}$ \\
\hline 9 & 132 & 130 & $131 \mathrm{~A}$ \\
\hline 12 & 132 & 133 & $133 \mathrm{~A}$ \\
\hline Ortalama & 128 & 127 & 128 \\
\hline
\end{tabular}

*: Aynı harfle gösterilen ortalamalar arasındaki farklar $\mathrm{P}<0.05$ düzeyinde önemsizdir

*: Differences between the means followed by the same letter are not significant at $P<0.05$ level

önemsiz bulunmuştur (Çizelge 6). Arıotu çeşitlerinin nispi besleme değerleri arasında istatistiki olarak farklılık belirlenmemiştir. Enton ve Stala çeşitlerinin ortalama nispi besleme değerleri sırasıyla, 128 ve 127 olarak belirlenmiştir. Gübre dozu ortalamaları incelendiğinde; artan gübre dozlarına bağıı olarak kontrol gübre dozunda nispi besleme değerleri 120 iken bu değer dekara 9 ve 12 $\mathrm{kg}$ olarak uygulanan azotlu gübre dozlarında sırasıyla 131 ve 133 olarak tespit edilmiştir (Çizelge 10). Linn ve Martin (1989), yem bitkilerinin nispi besleme değeri oranları için yaptıkları sınıflandırmada, yemin RFV oranı 151 'den büyükse o yemin en üstün kaliteli yem olduğunu, 125-151 aralığında yüksek kaliteli, 103-124 aralığında iyi kaliteli, 87-102 aralığında ise orta kaliteli buna karşılık 75-86 aralığında zayıf ve 75 'den düşük ise o yemin çok kötü kalitede olduğunu bildirmişlerdir. Bu sınıflandırmaya göre çalışmamızda nispi besleme değeri bakımından arıotu çeşitlerinin birbirlerine benzer olduğu ve kontrol parselleri hariç diğer gübre uygulanan parsellerden elde edilen arıotunun nispi besleme değerleri bakımından yüksek kaliteli olduğu söylenebilir.

\section{Sonuç}

Araştırmadan elde edilen sonuçlara göre; en yüksek yeşil ot ve kuru ot verimleri Enton çeşidinde dekara 6 ve $9 \mathrm{~kg}$ olarak uygulanan azotlu gübre dozunda, Stala çeşidinde ise dekara $9 \mathrm{~kg}$ olarak uygulanan azotlu gübre dozundan elde edilmiştir. En yüksek ham protein oranı dekara $6 \mathrm{~kg}$ ve üzeri miktarda uygulanan azotlu gübre dozlarında belirlenirken, ortalama en yüksek ham protein verimi ise $98.01 \mathrm{~kg} / \mathrm{da}$ ile dekara $9 \mathrm{~kg}$ olarak uygulanan azotlu gübre dozunda tespit edilmiştir. Araştırmada en düşük ADF ve NDF oranları ortalamaları kontrol parsellerinde tespit edilirken, azotlu gübre dozları arttıkça arıotunun ADF ve NDF oranlarında azalışlar TDN değerlerinde ise artış belirlenmiştir. En yüksek RFV değerleri kontrol parseli hariç diğer tüm azotlu gübreleme yapılan parsellerde belirlenmiştir. Araştırmadan elde edilen sonuçlara göre yeşil ot kuru ot ve ham protein verimi ile ham protein oranı, ADF ve NDF oranları ile nispi besleme değerleri dikkate alındığında Enton çeşidinin Stala çeşidine tercih edilmesi gerektiği, Yüksek verim ve kalitede arıotu için ise en uygun gübre dozunun dekara $9 \mathrm{~kg}$ olarak uygulanan azotlu gübre olduğu sonucuna varılmıştır.

\section{Teşekkür}

$\mathrm{Bu}$ çalışma, Süleyman Demirel Üniversitesi, Fen Bilimleri Enstitüsü Tarla Bitkileri Anabilim Dalında yürütülen yüksek lisans çalışmasının bir bölümünü içermektedir. 3805-YL1-13 proje numarası ile yürütülen bu 
çalışmayı destekleyen Süleyman Demirel Üniversitesi, Bilimsel Araştırma Projeleri Koordinasyon Birimine de teşekkürlerimizi sunarız.

\section{Kaynaklar}

Akkurt V., 2013. Farklı tohum ön uygulamalarının ve bitki hormonlarının arıotu (Phacelia tanacetifolia benth.) tohumlarında görülen ışık ve sıcaklık dormansisinin kırılması üzerine etkileri. Yüksek Lisans Tezi Kahramanmaraş Sütçü İmam Üniversitesi Fen Bilimleri Enstitüsü, Kahramanmaraş

Albayrak S., Türk M. ve Yüksel O., 2009. Effects of phosphorus fertilization and harvesting stages on forage yield and quality of woolypod vetch. Turkish Journal of Field Crops. 14(1): $30-40$

Ateş E., 2012. The mıneral, amıno acıd and fıber contents and forage yield of field pea (Pisum arvense L.), fiddleneck (Phacelia tanacetıfolıa benth.) and their mixtures under dry land conditions in the western turkey. Romanian Agricultural Research, 29, 237-244

Ates E., Tekeli A. S. and Boynukara B., 2014. Performance Of Fodder Pea (Pisum arvense L.) - Fiddleneck (Phacelia tanacetifolia Benth.) Mixture Under Different Nitrogen Doses. Romanian Agricultural Research, No. 31, 1-6

Aydın N., Mut Z., Mut H. ve Ayan İ., 2010. Effect of Autumn and Spring Sowing Dates on Hay Yield and Quality of Oat (Avena sativa L.) Genotypes. Journal of Animal and Veterinary Advances. 9(10): 1539-1545

Dağ V., 2013. Farklı azot dozlarının arıotu (Phacelia tanacetifolia Bentham )'nda verim ve bazı tarımsal karakterlere etkisi. Yüzüncü Yıl Üniversitesi Fen Bilimleri Enstitüsü Tarla Bitkileri Anabilim Dalı, 48s

Djordjevic N., Dinic B., Grubic G., Vuckovic S. and Simic A., 2005. The quality and chemical composition of Phacelia tanacetifolia Benth. and lucerne silages. Integrating efficient grassland farming and biodiversity. Proceedings of the $13^{\text {th }}$ International Occasional Symposium of the European Grassland Federation, Tartu, Estonia, 29-31 August 20052005 pp. 294-297

Ercan R. ve Bildik E., 1993. Azotlu gübre uygulamasının ekmeklik buğday kalitesine etkisi. Gıda 18(3):165- 171

Geren H. ve Kaymakkavak D., 2007. Farklı Sıra Arası Uzaklıklarının Kimi Arıotu (Phacelia tanacetifolia Bentham) Çeşitlerinde Ot Verimi ile Verim ve Kalite Özelliklerine Etkileri. Ege Üniv. Ziraat Fak. Derg., 2007, 44 (1): 71-85

Gromadzinski A., 1976. Influence of sowing dates and nitrogen fertilization on the yields of crops grown as the stubble aftercrop. Pamietnik Pulawski 1976 No. 66 pp. 155-166

Kucharski J., 1992. Suitability of nitrogen fertilizers with delayed action for the fertilization of phacelia and carrots. Acta Academiae Agriculturae ac Technicae Olstenensis, Agricultura, 54(11): pp. 43-52

Linn J. and Martin N. P., 1989. Forage quality tests and interpretation. Minnesota EXT. Service. AG-FO-2637. Universityt of Minnesota, Saint Paul

SAS Institute., 1998. INC SAS/STAT users' guide release 7.0, Cary, NC, USA

Sezer Y., 1991. Gübreler ve gübreleme, Atatürk Üniversitesi yayınları No.679 Ziraat Fakültesi Yayınları No. 3003, Ders kitapları, Seri No. 55 Erzurum

Wilczewski E., Leman'czyk G., Skinder Z. and Sadowski C., 2006. Effect of nitrogen fertilization on the yielding and health status of selected nonpapilonaceous plant species grown in stubble intercrop. Electronic Journal of Polish Agricultural Universities 2006 Vol. 9 No. 2

Wilczewski E., Skinder Z. and Szczepanek M., 2008. Effect of the nitrogen dose on qualitative characters of green forage made of nonpapilionaceous plants grown in stubble intercrop. Acta Scientiarum Polonorum Agricultura. 7 (2): 133-141

Wilczewski E., Skinder Z. and Wydawnictwa M., 2009. Influence of nitrogen fertilization on macronutrients content in the postharvest residue of non-papilionaceous plants cultivated in stubble intercrop. Acta Scientiarum Polonorum - Agricultura, 8 (2): 77-86 